\title{
A critical appraisal of lubiprostone in the treatment of chronic constipation in the elderly
}

\author{
This article was published in the following Dove Press journal: \\ Clinical Interventions in Aging \\ 14 February 2013 \\ Number of times this article has been viewed
}

\author{
Beatriz Gras-Miralles' \\ Filippo Cremonini ${ }^{1,2}$ \\ 'Gastroenterology Department, \\ Beth Israel Deaconess Medical Center, \\ Harvard Medical School, Boston, MA, \\ USA; ${ }^{2}$ Southern Nevada VA Healthcare \\ System, Las Vegas, NV, USA
}

Correspondence: Filippo Cremonini Rabb Rose I, Beth Israel Deaconess Medical Center, 330 Brookline Avenue, Boston, MA, 02215, USA

$\mathrm{Tel}+\mid$ 617-667-2|38

Fax+| 6|7-667-||17|

Email fcremoni@bidmc.harvard.edu

\begin{abstract}
Chronic constipation is a common disorder in the general population, with higher prevalence in the elderly, and is associated with worse quality of life and with greater health care utilization. Lubiprostone is an intestinal type- 2 chloride channel activator that increases intestinal fluid secretion, small intestinal transit, and stool passage. Lubiprostone is currently approved by the US Food and Drug Administration for the treatment of chronic idiopathic constipation and of irritable bowel syndrome with predominant constipation. This review outlines current approaches and limitations in the treatment of chronic constipation in the elderly and discusses the results, limitations, and applicability of randomized, controlled trials of lubiprostone that have been conducted in the general and elderly population, with additional focus on the use of lubiprostone in constipation in Parkinson's disease and in opioid-induced constipation, two clinical entities that can be comorbid in elderly patients.
\end{abstract}

Keywords: irritable bowel syndrome, Parkinson's disease, opioid-induced constipation, chronic constipation

\section{Introduction}

The progressive increase in life expectancy in developed countries has led to a corresponding rise in the proportion of elderly population. In the United States, the population aged 65 and older was 40.2 million in 2010 and is projected to be 88.5 million in 2050. ${ }^{1}$ This exponential increase poses a number of challenges, as diseases and conditions that are more prevalent in elderly patients will need a much greater allocation of resources and expertise in health care systems in future years.

Chronic constipation (CC) is a common disorder, with an estimated prevalence of $12 \%-19 \%$ in the general population (depending on the area and the criteria used for the diagnosis). ${ }^{2}$ A multinational survey published in 2008 that included 13,879 adults from seven different countries (United States, United Kingdom, Germany, France, Italy, Brazil, and South Korea) found a prevalence of constipation symptoms of $12.3 \%$ in the adult population (range 5\%-18\%), with odds ratios for constipation in women and elderly of 2.43 (95\% CI: 2.18-2.71) and 1.5 (95\% CI: $1.25-1.73$ ), respectively. ${ }^{3}$ This same study reported a prevalence of use of laxatives among those with constipation between 16\%-40\%. Increasing age, symptom frequency, and lower income and education were individual factors associated with laxative use.

A survey performed in Olmsted (Minnesota, USA), specifically designed for elderly responders ( $\geq 65$ years old, mean age 76 ), found a constipation prevalence of $40.1 \%(95 \%$ CI: 38.9-44.4). Functional constipation, the most frequent category encountered in this study, had a prevalence of $24.4 \%$ (95\% CI: 22.0-26.9). ${ }^{4}$ In another study, performed using 
face-to-face interviews with frail elderly individuals who were not institutionalized, constipation was spontaneously mentioned by $45 \%$ of participants and was considered by $11 \%$ to be a major burden to their quality of life. ${ }^{5} \mathrm{CC}$ affects the majority of long-term patients in hospitals and residents in nursing homes, ${ }^{6}$ and often, with exorbitant prevalence (reported up to $50 \%-79 \%$ ) in the long-term institutionalized elderly. ${ }^{7}$

Although CC can be seen as a trivial medical problem, its impact on quality of life can be substantial and may result in considerable additional utilization of health care resources, including specialist visits, gastrointestinal diagnostic procedures, and medical treatment modalities. ${ }^{6,8}$ Using both diseasespecific and generic quality of life measurement instruments, studies suggest constipation is associated with impaired healthrelated quality of life, ${ }^{9,10}$ with CC patients exhibiting lower scores for physical functioning, mental health, general health perception, and bodily pain when compared with individuals without constipation. ${ }^{11}$ Medical relief of constipation in a group of 52 CC patients aged 65-89 years resulted in improvement of patient's mood, sexual activity, and quality of life. ${ }^{12}$

In the United States, CC accounts for more than 2.5 million visits to physicians and for laxative sales of several hundred million dollars a year. ${ }^{13}$ In England and Wales, constipation generated some 450,000 general practice consultations per year in 1991 and 1992, at an estimated cost of $£ 4.5$ million per year. ${ }^{8}$ Data from the UK National Survey of morbidity data in general practice showed an age-dependent increase in the consultation rates for constipation, from 75/100,000 person-year for the 45-64 age group, to 400/100,000 personyear for the 77-84 age group. ${ }^{14}$

Lubiprostone (Amitiza ${ }^{\circledR}$, Sucampo Pharmaceuticals) was approved in the United States in 2006 for the treatment of chronic idiopathic constipation (CIC) in men and women, and in 2008 for women with irritable bowel syndrome with predominance of constipation (IBS-C). Since then, several studies focusing on lubiprostone efficacy and use have been published. Aims of this review were: (1) to review the current available treatments of CC in the elderly population; (2) to summarize the pharmacological properties of lubiprostone and data on its effects on constipation, based on studies in the general population; (3) to evaluate the data supporting the use of lubiprostone in the elderly; and (4) to discuss the studies performed using lubiprostone in specific situations occurring more frequently in older people, including Parkinson's disease (PD) and opioid-induced constipation (OIC).

For the purpose of the present review, publications in abstract form and full papers on lubiprostone clinical studies were searched from 1995 to October 2012 on the PubMed electronic database and from proceedings of gastroenterology international meetings, using combinations of the following keywords: constipation, chronic, idiopathic, elderly, lubiprostone, Amitiza, opioid-induced, and Parkinson's.

\section{Constipation in the elderly population \\ Pathophysiology, onset and clinical features}

The underlying mechanisms for CC in older adults include primary slow colonic transit, pelvic floor dysfunction, or a combination of the two. The role of reduced fiber and fluid intake and decreased physical activity is questionable, whereas underlying health problems more prevalent with advanced age (eg, diabetes mellitus, PD, dementia) and the use of medications (ie, calcium supplements, opioids, certain antidepressants) potentially affecting gastrointestinal motility and evacuation of stools are often involved (Table 1). The above factors can intervene, with advancing age, to worsen common underlying disorders already present from a younger age, such as CIC or IBS-C. CC in the elderly, if severe,

Table I Common causes of constipation in elderly patients

\begin{tabular}{|c|c|}
\hline \multirow[t]{8}{*}{ Gastrointestinal disorders } & Irritable bowel syndrome \\
\hline & Anorectal disorders \\
\hline & (ie, hemorrhoids, anal fissures) \\
\hline & Diverticulitis \\
\hline & Hernias \\
\hline & Intestinal volvulus \\
\hline & Tumors \\
\hline & Upper gastrointestinal tract disorders \\
\hline \multirow[t]{6}{*}{ Metabolic disorders } & Diabetes mellitus \\
\hline & Chronic kidney disease \\
\hline & Hypothyroidism \\
\hline & Hyperparathyroidism \\
\hline & Hypercalcemia \\
\hline & Panhypopituitarism \\
\hline \multirow[t]{5}{*}{ Neurogenic disorders } & Cerebrovascular accidents \\
\hline & Parkinson's disease \\
\hline & Spinal cord injury (ie, spinal canal stenosis) \\
\hline & Tumors of the central nervous system \\
\hline & Trauma to the brain or the medulla \\
\hline \multirow[t]{2}{*}{ Psychogenic causes } & Voluntarily ignore or postpone defecation \\
\hline & Psychiatric disease \\
\hline \multirow[t]{10}{*}{ Medications } & Nonsteroidal anti-inflammatory agents \\
\hline & Opiates \\
\hline & Calcium channel blockers \\
\hline & Diuretics (nonpotassium sparing) \\
\hline & Iron supplements \\
\hline & Antihistamine \\
\hline & Anticholinergics \\
\hline & Tricyclic antidepressants \\
\hline & Antipsychotics \\
\hline & $\begin{array}{l}\text { Antacids containing calcium carbonate or } \\
\text { aluminum hydroxide }\end{array}$ \\
\hline
\end{tabular}


entails a substantial rate of complications, with subsequent increase of limitation to independent activities of daily life and hospitalization rate. A wide range of complications can be associated, from anorectal pathology (eg, fissures, hemorrhoids, rectal prolapse, etc) to sigmoid volvulus, fecal impaction, fecal incontinence, and urinary dysfunction. ${ }^{15}$

\section{Available therapies}

Nonpharmacological treatments for constipated patients include lifestyle and dietary measures, such as exercise, modifications to the daily routine, adequate fiber, and water intake. These measures are often difficult to implement in the elderly population, as multiple obstacles ranging from limited mobility to deglutition and mastication problems frequently exist in this group.

In patients with $\mathrm{CC}$ and associated pelvic floor dysfunction, pelvic floor retraining using biofeedback techniques has shown to be effective and have durable results. ${ }^{16,17}$ The prevalence of pelvic floor dysfunction in $\mathrm{CC}$ has been estimated to be $50 \%$ or more, in studies in tertiary care centers ${ }^{18}$ and is more frequent in patients with history of anorectal surgery or other pelvic floor trauma. A single study of 30 elderly adults with CC showed good response to a combined approach of physiological and psychological therapy. ${ }^{19}$ When treating elderly populations, one should bear in mind that biofeedback efficacy may be limited by patients' declining physical or mental abilities.

Pharmacological treatment comprises several types of laxatives, including bulk-forming agents (such as psyllium, calcium polycarbophil, and methylcellulose), stool softeners (such as docusate sodium and docusate calcium), osmotics or salines (such as magnesium hydroxide, lactulose, polyethylene glycol, sorbitol, and glycerin rectal suppositories), and stimulants (such as senna, cascara sagrada, castor oil, and bisacodyl).

Self-medication is common in CC. Laxatives are widely available and remain agents of first choice. It has been reported that up to $16 \%$ of individuals aged 65 and above use over-the-counter laxatives, women more often than men. ${ }^{20-24}$ The use of laxatives has been associated with a greater number of physician or emergency room visits and more frequent hospitalization, home health services utilization, and prescription drugs use. ${ }^{21}$ Among laxatives, the osmotic preparation polyethylene glycol 3350 has been shown to be safe and effective in elderly populations. ${ }^{25-26}$ However, clinical trials targeted to the elderly are lacking.

Limited patient compliance, polypharmacy, and patientprovider miscommunication can all contribute to poor understanding of the laxative dose and mode of administration, resulting in suboptimal results.

In the elderly with $\mathrm{CC}$, prescription agents have been, in general, much less used than over-the-counter laxatives, owing to the limited drug choice, to cost issues, and to potential safety concerns.

Linaclotide is an agonist of guanylate cyclase $2 \mathrm{C}$ that was recently approved by the US Food and Drug Administration (FDA) for treatment of CIC and IBS-C. A 4-week multicenter clinical trial with 310 CIC patients included 30 elderly subjects, who showed similar results in safety and improvement of weekly spontaneous bowel movements (SBMs), stool consistency, straining, abdominal discomfort, and quality of life to the entire study population. ${ }^{27}$

Prucalopride is a $5-\mathrm{HT}_{4}$ receptor agonist that was approved in some European countries in 2009 and in Canada in 2011, but not in the US, for the treatment of CIC. A 4-week, placebo-controlled, Phase III trial with 300 elderly patients (mean age of $76.4 \pm 0.4$ years) showed significant improvement in the number of SBMs/week and quality of life in the treatment group and that the treatment was safe and well tolerated. ${ }^{28}$ A 28-day Phase II study of 89 elderly CIC institutionalized patients also showed good treatment tolerability and absence of significant adverse events. ${ }^{30}$

Several reviews discuss clinical trials performed with elderly patients and the current recommendations for treating this population. Regrettably, the guidelines provided are only in part evidence-based, owing to the general lack of large, randomized, controlled trials. ${ }^{8,10,30}$ Overall, they call for the need to take into account the patient's specific features (eg, ambulatory versus institutionalized, use of concomitant medications), to individualize the clinical approach. The final goals remain the achievement of acceptable bowel function (associated with better quality of life) and prevention of adverse effects of medications, in this vulnerable population.

\section{Lubiprostone: pharmacology and physiological effects}

Lubiprostone is classified as a prostone, a bicyclic fatty acid compound derived from a metabolite of prostaglandin E1. Lubiprostone acts locally in the small intestinal lumen, inducing secretion of fluid and electrolytes through the activation of the type- 2 chloride channels in the intestinal apical cell membrane (Figure 1), ${ }^{6,31}$ and thereby accelerates the small bowel and colon transit times. In the upper gut, lubiprostone appears to delay gastric emptying and to increase stomach volumes in the fasting state. ${ }^{32}$ 


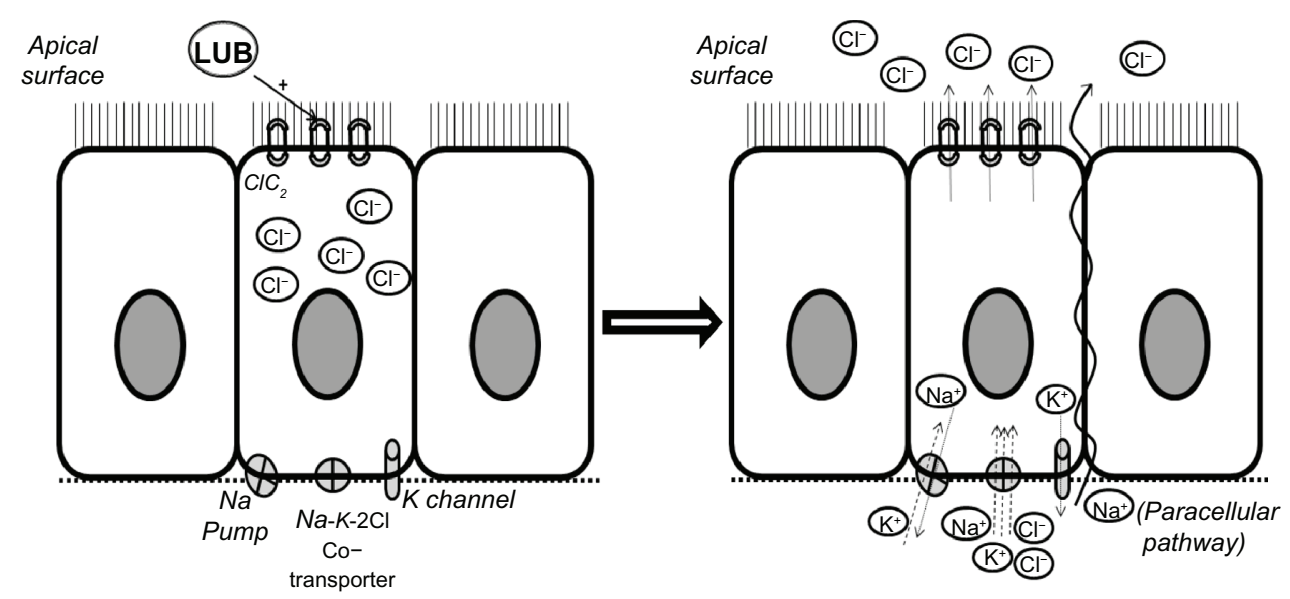

Figure I Summary of the mechanism of action of lubiprostone.

Notes: Chloride channels-2, present in the apical membrane of the intestine, are activated, resulting in increased secretion of chloride-rich intestinal fluid. Other channels secondarily act to maintain cellular homeostasis.

Abbreviations: LUB, lubiprostone; $\mathrm{ClC}_{2}$, chloride channels- 2 .

\section{Lubiprostone: clinical data in adults and elderly patients}

A summary of results from lubiprostone open-label and placebo-controlled studies of adult and elderly populations with CIC and IBS-C is presented in Tables 2-4.

\section{Patients with chronic idiopathic constipation}

A Phase II, double-blind, dose-ranging study randomized 129 subjects with symptoms of CIC, between 18-75 years old, to four groups receiving placebo or lubiprostone 24, 48, or 72 mcg daily, for 3 weeks. ${ }^{33}$ Mean SBMs frequencies were significantly higher for all lubiprostone groups, with better responses in the groups treated with higher doses. SBMs per week increased after the first 7 days of treatment with 48 and $72 \mathrm{mcg} /$ day, and all three lubiprostone groups presented an increase from fewer than 2 to 5-6 SBMs/week after 2 weeks. Patients also reported an improvement of stool consistency, straining, and abdominal bloating symptoms. However, the percentage of patients using rescue medication during the trial was not significantly different across the four treatment arms and during the 3 weeks. The higher dose also was associated with greater severity of adverse effects, including nausea, headache, and diarrhea and did not appear to provide a clear risk-benefit advantage when compared with lubiprostone $48 \mathrm{mcg} /$ day.

Subsequently, two Phase III trials randomized 479 adults with CIC to placebo or lubiprostone $48 \mathrm{mcg} / \mathrm{day}$

Table 2 Summary of clinical trials of lubiprostone in adult populations with chronic constipation

\begin{tabular}{|c|c|c|c|}
\hline Author & Patients & Description & Results \\
\hline $\begin{array}{l}\text { Johanson } \\
\text { et } \mathrm{al}^{34}\end{array}$ & $\begin{array}{l}\mathrm{N}=129 \\
\text { Age } 18-75 \\
>84 \% \text { women }\end{array}$ & $\begin{array}{l}\text { 3-week dose ranging study } \\
\text { ( } 24 \mathrm{mcg} / \mathrm{d}, 48 \mathrm{mcg} / \mathrm{d} \text { and } \\
72 \mathrm{mcg} / \mathrm{d} \text { doses })\end{array}$ & $\begin{array}{l}\text { Dose-dependent improvement SBM on day I, SBMs/week, stool consistency, } \\
\text { straining and bloating in lubiprostone arms, accompanied by incremental } \\
\text { incidence of adverse events (nausea, headache, and diarrhea). }\end{array}$ \\
\hline $\begin{array}{l}\text { Johanson } \\
\text { et } \mathrm{al}^{2}\end{array}$ & $\begin{array}{l}N=242 \\
\text { Age } 22-80 \\
90 \% \text { women }\end{array}$ & $\begin{array}{l}\text { 4-week single dose study } \\
\text { ( } 24 \text { mcg bid) }\end{array}$ & $\begin{array}{l}\text { Lubiprostone better than placebo on SBM on day I, SBMs/week after } \\
\text { week I, stool consistency, straining, abdominal bloating, abdominal } \\
\text { discomfort, and constipation severity. } \\
\text { Nausea more frequent in lubiprostone group ( } 31.7 \% \text { vs } 3.3 \% \text { in placebo } \\
\text { group). }\end{array}$ \\
\hline $\begin{array}{l}\text { Barish } \\
\text { et } \mathrm{al}^{34}\end{array}$ & $\begin{array}{l}N=237 \\
88.2 \% \text { women }\end{array}$ & $\begin{array}{l}\text { 4-week single dose study } \\
\text { ( } 24 \mathrm{mcg} \text { bid) }\end{array}$ & $\begin{array}{l}\text { Lubiprostone better than placebo on SBM on day I and SBMs/week } \\
\text { after week I. } \\
\text { Stool consistency, straining, and constipation severity. No significant } \\
\text { differences in abdominal bloating and discomfort. }\end{array}$ \\
\hline $\begin{array}{l}\text { Lembo } \\
\text { et } \mathrm{al}^{36}\end{array}$ & $\begin{array}{l}\mathrm{N}=248 \\
\text { Mean age } \\
51 \pm 14 \\
83.9 \% \text { women }\end{array}$ & $\begin{array}{l}\text { 48-week open-label, single dose study } \\
\text { ( } 24 \text { mcg bid) } \\
\text { One subgroup enrolled after } \\
\text { a placebo-controlled withdrawal phase }\end{array}$ & $\begin{array}{l}\text { Significant reduction from baseline, in constipation severity, abdominal } \\
\text { bloating, and abdominal discomfort. }\end{array}$ \\
\hline
\end{tabular}

Abbreviations: bid, twice daily; SBM, spontaneous bowel movement. 
Table 3 Summary of clinical trials of lubiprostone in adult populations with IBS and predominant constipation

\begin{tabular}{|c|c|c|c|}
\hline Author & Patients & Description & Results \\
\hline $\begin{array}{l}\text { Drossman } \\
\text { et } \mathrm{al}^{37}\end{array}$ & $\begin{array}{l}N=|17| \\
\text { Age } 18-85 \\
92 \% \text { women }\end{array}$ & $\begin{array}{l}\text { Two } 12 \text {-week } \\
\text { Single dose }(8 \mathrm{mcg} \text { bid }) \\
\text { trials }\end{array}$ & $\begin{array}{l}\text { Higher rate of overall responders (subjective rate of relief of IBS symptoms): } \\
\text { in lubiprostone group }(17.9 \%) \text { than placebo }(10.1 \%) \text {, maintained throughout the study. } \\
\text { Improvement in abdominal discomfort/pain, bloating, constipation severity, stool } \\
\text { consistency, and straining }(P<0.00 I) \text {. Trends in improvement in IBS-QOL measures. }\end{array}$ \\
\hline Chey et $\mathrm{a}^{38}$ & $\begin{array}{l}\mathrm{N}=520 \\
\text { Age } 21-82 \\
93 \% \text { women }\end{array}$ & $\begin{array}{l}\text { 36-week } \\
\text { Single dose ( } 8 \mathrm{mcg} \text { bid) } \\
\text { open-label trials } \\
\text { extension of placebo- } \\
\text { controlled studies }\end{array}$ & $\begin{array}{l}\text { Overall subjective rate of relief was } 16 \% \text { after I month, } \\
23 \%-39 \% \text { after } 2-5 \text { months, } 37 \%-44 \% \text { after } 10-13 \text { months of lubiprostone treatment. } \\
\text { Increase in SBMs/week after the first month of treatment, maintained at } \\
\text { approximately } 5 \text { SBMs/week throughout the treatment period, with improvement in } \\
\text { abdominal discomfort/pain, abdominal bloating, and stool consistency after the first } \\
\text { month and throughout the study }(P<0.00 \mathrm{I}) \text {. Most common adverse events were } \\
\text { nausea and diarrhea (both II\%). }\end{array}$ \\
\hline
\end{tabular}

Abbreviations: IBS, irritable bowel syndrome; bid, twice daily; QOL, quality of life; SBM, spontaneous bowel movement.

for 4 weeks. ${ }^{2,34}$ In the lubiprostone group, a significant increase of SBMs/week was seen starting after the first week of treatment, along with improvement in stool consistency, straining, and constipation severity that was maintained throughout the 4 weeks. The requirement of rescue laxatives was lower in the lubiprostone group, but only in one of the trials was this difference statistically significant. ${ }^{2}$ More than $40 \%$ of patients in the active treatment groups reported at least one adverse effect during the studies, which led to the withdrawal of the drug in approximately $7 \%$ of patients overall. Nausea was the side effect reported most commonly (24\%-32\%).

A meta-analysis on lubiprostone data from 610 patients with CIC, ${ }^{35}$ using self-reported relief of symptoms by patients as the main outcome measure, concluded that treatment during 3 or 4 weeks with lubiprostone $48 \mathrm{mcg} /$ day was more effective than placebo (55\% vs $33.1 \%$ of responders). The calculated number needed to treat was 5 (95\% CI: 3-7). Adverse events, mostly diarrhea and nausea, were also overall more frequent in the lubiprostone-treated patients $(60 \% \mathrm{vs}$ $34 \%$ taking placebo).

A long-term, prospective, multicenter, open-label trial included 248 CIC patients to be treated with lubiprostone $48 \mathrm{mcg}$ /day versus placebo, during 48 weeks. ${ }^{36}$ Lubiprostone was more effective at reducing constipation severity, abdominal bloating, and discomfort. To minimize the impact of side effects occurrence on treatment withdrawals, the study design allowed dose reduction of lubiprostone when side effects occurred, at the discretion of the investigators, and redosing was performed in $17 \%$ of patients. Most lubiprostone-related adverse effects were mild (50\%) or moderate (44\%), and the most frequent were nausea (19.8\%) and diarrhea (9.7\%). Other adverse effects included abdominal distension, headache, abdominal pain, and vomiting. Overall, $13.3 \%$ of patients withdrew from the study due to adverse effects.

\section{Patients with irritable bowel syndrome with predominant constipation}

A combined analysis of two Phase III randomized trials involving 1171 patients who met Rome II criteria for IBS-C was performed comparing lubiprostone $16 \mathrm{mcg}$ /day with placebo, for 12 weeks. ${ }^{37}$ The patients were predominantly female (91.6\%), 18-85 years old. The total number of overall responders (response was defined as moderate to significant IBS symptom relief, according to an electronic diary) was significantly higher in the lubiprostone group (17.9\% versus $10.1 \%$ ). Symptoms of abdominal discomfort or pain, bloating, constipation severity, straining, or stool consistency also improved significantly. The most frequent adverse effects were related to the gastrointestinal tract (ie, nausea, diarrhea, and abdominal distension) and had similar incidence in both groups.

Table 4 Summary of clinical trials of lubiprostone in elderly adults

\begin{tabular}{|c|c|c|c|}
\hline Author & Patients & Description & Results \\
\hline Ueno et $\mathrm{al}^{39}$ & $\begin{array}{l}N=57 \\
\text { Age } \geq 65\end{array}$ & $\begin{array}{l}\text { Subanalysis of } 3 \text { pooled placebo- } \\
\text { controlled single dose ( } 24 \text { mcg bid) } \\
\text { clinical trials of } 3-4 \text { weeks duration }\end{array}$ & $\begin{array}{l}\text { Significant improvement in lubiprostone group, in weeks I, } 3 \text {, and } \\
4 \text {, of SBMs rates stool consistency, and bowel straining rates. } \\
\text { Lesser adverse events in the lubiprostone group. }\end{array}$ \\
\hline Ueno et $\mathrm{al}^{40}$ & $\begin{array}{l}N=878 \\
(N=163, \text { age } \\
\geq 65, N=715 \\
\text { age } 18-64)\end{array}$ & $\begin{array}{l}\text { Subanalysis of } 3 \text { pooled } 48 \text {-week } \\
\text { single dose ( } 24 \text { mcg bid) placebo- } \\
\text { controlled trials }\end{array}$ & $\begin{array}{l}\text { Significant improvement, in elderly and nonelderly groups, of constipation } \\
\text { severity, abdominal bloating, and discomfort. } \\
\text { Incidence of nausea: } 17.8 \% \text { in elderly vs } 29.4 \% \text { in nonelderly patients. }\end{array}$ \\
\hline
\end{tabular}

Abbreviations: bid, twice daily; SBM, spontaneous bowel movement. 
An extension of this study was performed in 520 patients, mostly female (92.9\%), with an age range of 21-82 years, for a total of 52 weeks. ${ }^{38}$ Patients were randomized to three groups, according to the previous treatment, and received sequential treatment with placebo-lubiprostone, lubiprostone-lubiprostone, or lubiprostone-placebolubiprostone. The response rates to lubiprostone tended to improve over time, from $16 \%$ after 1 month, $32 \%-35 \%$ at 6-9 months, to $37 \%-44 \%$ after $10-13$ months of treatment. Individually, symptoms of abdominal discomfort and pain, abdominal bloating, and stool consistency were significantly improved throughout the study. Rescue medication was required by $31.5 \%$ patients overall. Nausea and diarrhea were the most common treatment-related adverse effects, and $10.4 \%$ of patients discontinued treatment or experienced a dose reduction due to one of these adverse events.

\section{Elderly patients}

Generally, extrapolation of the results of clinical trials performed in the overall adult population to elderly patients must be done with caution. Data from three open-label clinical trials were combined to obtain a pool of elderly patients with CIC. These analyses were published as abstracts, with the available data assessing a limited range of outcomes.

A group of 57 patients aged $\geq 65$ years was randomized to placebo or lubiprostone $48 \mathrm{mcg} / \mathrm{day}$ and followed for 4 weeks. In the lubiprostone group, a significant improvement in SBMs frequency (4.6-5.4 additional SBMs/week compared with 1.29-2.27 in the placebo group) and stool consistency was seen at week 4 . Fewer patients in the lubiprostone arm experienced related adverse effects than those receiving placebo $(46.2 \%$ vs $61.3 \%){ }^{39}$

Another group of 163 elderly constipated patients was compared with a group of 715 nonelderly lubiprostone trial participants. Tolerability and efficacy of lubiprostone $48 \mathrm{mcg} /$ day was assessed for 6 to 12 months. There was a significant improvement in constipation severity, abdominal bloating, and abdominal discomfort, at all postbaseline time points from week 1 to week 48, for both groups. Constipation severity appeared consistently improved throughout the study. The incidence rate for nausea, the most common adverse effect, was markedly less frequent in elderly subjects when compared to their nonelderly counterparts $(17.8 \%$ vs $29.4 \%){ }^{40}$ In a separate subanalysis, nausea occurred in only $18.8 \%$ of elderly patients, when the overall rate of nausea was $31.1 \%{ }^{41}$

Although these results are encouraging, additional studies, with more patients, are required before confirming the efficacy and safety of the treatment in elderly patients.

\section{Approved use of lubiprostone in $\mathrm{ClC}$ and IBS-C}

Based upon the results of these pivotal studies, the FDA approved lubiprostone use for the treatment of adult men and women with CIC (at the dose of $24 \mathrm{mcg}$, twice daily) and for the treatment of adult women with IBS-C (at the dose of $8 \mathrm{mcg}$, twice daily).

The incidence of adverse effects appears to be doserelated, improving after the discontinuation of the treatment. These effects include diarrhea, nausea, abdominal pain or discomfort, and bloating and, less frequently, extraintestinal complaints, including stomatitis, headache, dyspnea, vertigo, or palpitations. ${ }^{6,31,33}$ No alterations in the electrocardiogram were reported in one study performed on 177 patients with $\mathrm{CIC}$ and 68 healthy volunteers. ${ }^{42}$

\section{Lubiprostone: clinical data in specific situations Parkinson's disease}

$\mathrm{PD}$ is the second most common neurodegenerative disease in the United States, after Alzheimer's disease, with a point prevalence of at least one million affected individuals and about 50,000-60,000 new cases diagnosed annually. Incidence and prevalence of PD increase with age, with average disease onset at 60 years of age. Greater disease severity and higher doses of dopaminergic medications seem closely related to patients' age and to more severe autonomic problems in PD. Autonomic dysfunction affects activities of daily life and health-related quality of life in $\mathrm{PD} .{ }^{43}$ Constipation is among the most common symptoms related to autonomic dysfunction in PD. Severe constipation in PD may eventually lead to megacolon, intestinal pseudo-obstruction, volvulus, and bowel perforation. ${ }^{43}$ Its mechanisms include delayed gastric emptying, small intestine, and colonic transit time, difficulties with the volitional defecation process, and medication side effects. These digestive abnormalities are in part secondary to the early involvement in PD of the dorsal motor nucleus, which controls the majority of parasympathetic innervation to the gut; the loss of dopaminergic neurons and deposition of $\alpha$-synuclein in the myenteric ganglia and in the abdominopelvic autonomic plexus also likely play a role, resulting in dysregulation of the enteric nervous system..$^{43-45}$ Derangement of the volitional defecation process manifests clinically as impaired stool evacuation and is commonly the result of lack of coordination between the muscles in the pelvic floor and between these and the muscle groups involved in change of intra-abdominal pressure. ${ }^{44}$ 
Although levodopa is generally not very effective in the treatment of gastrointestinal symptoms in PD patients, ${ }^{43}$ its intrajejunal continuous infusion in patients with advanced PD showed improvement in constipation, in a study of 22 patients. ${ }^{46}$ There are a few trials evaluating the use of bulking agents, such as dietary fibers, psyllium, and polycarbophil, performed with a small number of PD patients. ${ }^{47-49}$ Fiber supplementation seems to improve stool consistency and frequency, but not colonic transit, and also enhances the delivery of dopaminergic agents, which may allow better control of symptoms. ${ }^{47-50}$ The efficacy and safety of polyethylene glycol was evaluated in an 8-week, double-blind, placebo-controlled study of 57 PD patients, with significant improvement in SBMs frequency and stool consistency. ${ }^{51}$ Pyridostigmine bromide, a reversible cholinesterase inhibitor, might have a possible beneficial effect and has been proposed as a safe option in case reports. ${ }^{52}$ Cisapride, a $5-\mathrm{HT}_{4}$ receptor agonist prokinetic, now withdrawn from the US market, was associated with faster colonic transit in a small, open-label PD study. ${ }^{53}$ The selective 5- $\mathrm{HT}_{4}$ receptor agonist and partial $5-\mathrm{HT}_{3}$ antagonist mosapride was also found to accelerate colonic transit time and improve evacuation, in another openlabel, 3-month study of PD patients. Lastly, botulinum toxin injections have been proposed as treatment in cases of focal dystonia of the puborectalis muscle in PD patients; however, controlled data are lacking to support this. ${ }^{54}$

In a double-blind, placebo-controlled study of 54 patients with CC and PD, mean age $67.0 \pm 10.1$ years, ${ }^{44}$ treatment with lubiprostone $48 \mathrm{mcg} /$ day over 4 weeks was well tolerated, increased stools per day, and improved subjective rating of constipation by visual analog scale score and questionnaires. The most commonly reported side effect was the occurrence of loose stools, in $48 \%$ of the lubiprostone-treated patients versus $3.7 \%$ in the placebo group. These were of mild severity and did not lead to treatment discontinuation. Of note, no patient receiving lubiprostone reported nausea. The duration of the study was limited; however, it suggests that use of lubiprostone in PD might be beneficial, without posing additional safety concerns.

\section{Opioid-induced constipation}

Opioid narcotics are commonly prescribed in the United States for both cancer and noncancer pain. It is estimated that $90 \%$ of patients presenting to pain centers and receiving treatment in such facilities are managed with opioids. ${ }^{55}$ In elderly patients, chronic pain is highly prevalent, with $45 \%-85 \%$ of elderly patients reporting pain in moderate to severe degree, ${ }^{56}$ and with the de facto common use of opioid narcotics, such as morphine, fentanyl, or oxycodone, despite the overall lack of clinical data to support the effectiveness and safety of these drugs in the elderly population..$^{57}$ Alongside their analgesic properties, opioids carry the burden of inducing cognitive impairment, cough depression, addiction, and sensory and motor dysfunction throughout the bowel, and are associated with a wide range of gastrointestinal manifestations. ${ }^{58}$ Constipation is the most common gastrointestinal adverse effect of opioid narcotics, with an incidence about $40 \% .^{59,60}$

Alvimopan and methylnaltrexone, two peripherally acting antagonists of the $\mu$-opioid receptors with restricted ability to cross the blood-brain barrier, have demonstrated efficacy and safety in the treatment of OIC, without reversing the central effects of analgesia. ${ }^{61,62}$ Alvimopan has been approved by the FDA as a short-term treatment to accelerate the time of upper and lower gastrointestinal recovery after bowel resection. ${ }^{63}$ Methylnaltrexone has been approved to treat $\mathrm{OIC}$ in patients with advanced illness receiving palliative care, when the response to laxatives has been insufficient. ${ }^{64}$ Additional pharmacodynamic and clinical data suggest methylnaltrexone has potential effects on gastric emptying, on relief of nausea and vomiting, and on reduction of episodes of airway aspiration. ${ }^{65}$

Lubiprostone has been a potential candidate in OIC treatment. Studies performed on animal ${ }^{66}$ and human intestinal tissues ${ }^{67}$ suggested lubiprostone has the potential to counteract the inhibition by morphine of secretomotor neurons in the enteric nervous system of the small intestine. Four double-blind, Phase III clinical trials, one of them an extension of two previous ones, were performed in Europe, Canada, and the United States. They compared lubiprostone $48 \mathrm{mcg} /$ day to placebo, in adults with OIC secondary to treatment with a full-agonist opioid for chronic, noncancer-related pain. Two of these have been published as abstracts. ${ }^{68,69}$

One 12-week trial (NCT00595946) included 443 subjects. The lubiprostone-treated group showed significant improvement in SBMs/week, constipation severity, stool consistency, abdominal discomfort, and straining. This range of effects was not observed in patients on methadone. ${ }^{68} \mathrm{~A}$ second 12-week trial (NCT01298219) enrolled 439 patients, excluding patients treated with methadone. ${ }^{69}$ The lubiprostone-treated group reported significantly higher response in terms of SBMs compared with patients receiving placebo $(26.9 \%$ vs $18.6 \%$ ). Straining, stool consistency, abdominal discomfort, and constipation severity were also significantly improved. In a separate trial (NCT00597428), however, conducted in 420 adults over 12 weeks, lubiprostone did not show significant difference in the improvement of SBMs/week compared with placebo, although a significant improvement was found in the secondary end points of stool consistency, abdominal 
discomfort, constipation severity, and straining. As seen in the previous studies, the subgroup of patients on methadone treatment showed lower response rates. ${ }^{70}$

A Phase III extension of NCT00595946 and NCT00597428 was later performed in the United States. It included 439 adults that were followed for 36 weeks. According to data filed by the drug manufacturer, a maintained improvement of SBM compared with baseline was observed, while remaining on lubiprostone. ${ }^{71}$

The most common adverse effects in these trials were diarrhea, nausea, and abdominal pain or discomfort, which were reported by less than $10 \%$ of patients, but without affecting analgesia.

OIC is not an FDA-approved indication for treatment with lubiprostone. While lubiprostone might represent an additional option in OIC, it is unclear how its efficacy would compare with that of selective, peripheral opioid reversal agents available and in clinical development, and additional studies might be needed.

\section{Conclusion}

$\mathrm{CC}$ is highly prevalent in the general population and especially among elderly patients. It can worsen quality of life and significantly impair activities of daily living. There is an unmet need for safe and effective CC treatments in the elderly. Lubiprostone is approved for the treatment of $\mathrm{CC}$ and IBS-C in the general population. Lubiprostone has also shown efficacy in smaller studies of constipation in the context of PD and seems promising as a treatment modality for OIC, two situations found more frequently in elderly populations. Lubiprostone use is limited by the incidence of gastrointestinal side effects, most notably nausea, which can only in part be modulated by dose reduction.

Few data are available on lubiprostone use for CC in elderly patients. These data seem to support a comparable range of efficacy to that described in other adult populations and do not show a high incidence of nausea, although the statistical power of this elderly patient sample is likely limited. The available evidence supports, with the limitations discussed above, the efficacy and safety of lubiprostone for CC treatment in the elderly.

\section{Disclosure}

The authors report no conflicts of interest in this work.

\section{References}

1. Vincent GK, Velkoff VA. The Next Four Decades. The Older Population in the United States: 2010 to 2050. Washington: US Census Bureau; 2010. Available from: http://www.census.gov/prod/2010pubs/p25-1138. pdf. Accessed December 18, 2010.
2. Johanson JF, Morton D, Geenen J, Ueno R. Multicenter, 4-week, double-blind, randomized, placebo-controlled trial of lubiprostone, a locally-acting type- 2 chloride channel activator, in patients with chronic constipation. Am J Gastroenterol. 2008;103(1):170-177.

3. Wald A, Scarpignato C, Mueller-Lissner S, et al. A multinational survey of prevalence and patterns of laxative use among adults with self-defined constipation. Aliment Pharmacol Ther. 2008;28(7):917-930.

4. Talley NJ, Fleming KC, Evans JM, et al. Constipation in an elderly community: a study of prevalence and potential risk factors. Am J Gastroenterol. 1996;91(1):19-25.

5. Wolfsen CR, Barker JC, Mitteness LS. Constipation in the daily lives of frail elderly people. Arch Fam Med. 1993;2(8):853-858.

6. Fukudo S, Hongo M, Kaneko H, Ueno R. Efficacy and safety of oral lubiprostone in constipated patients with or without irritable bowel syndrome: a randomized, placebo-controlled and dose-finding study. Neurogastroenterol Motil. 2011;23(6):544-e205.

7. Bosshard W, Dreher R, Schnegg JF, Büla CJ. The treatment of chronic constipation in elderly people: an update. Drugs Aging. 2004;21(14):911-930.

8. Mihaylov S, Stark C, McColl E, et al. Stepped treatment of older adults on laxatives. The STOOL trial. Health Technol Assess. 2008; 12(13):iiiiv, ix-139.

9. O'Keefe EA, Talley NJ, Zinsmeister AR, Jacobsen SJ. Bowel disorders impair functional status and quality of life in the elderly: a population-based study. J Gerontol A Biol Sci Med Sci. 1995;50(4): M184-M189.

10. Rao SS, Go JT. Update on the management of constipation in the elderly: new treatment options. Clin Interv Aging. 2010;5:163-171.

11. Glia A, Lindberg G. Quality of life in patients with different types of functional constipation. Scand J Gastroenterol. 1997;32(11):1083-1089.

12. Charach G, Greenstein A, Rabinovich P, Groskopf I, Weintraub M. Alleviating constipation in the elderly improves lower urinary tract symptoms. Gerontology. 2001;47(2):72-76.

13. Lembo A, Camilleri M. Chronic constipation. N Engl J Med. 2003; 349(14):1360-1368.

14. McCormick A, Fleming D, Charlton J. Morbidity Statistics from General Practice: Fourth National Study: 1991-1992. London: HMSO; 1995.

15. McCrea GL, Miaskowski C, Stotts NA, Macera L, Varma MG. A review of the literature on gender and age differences in the prevalence and characteristics of constipation in North America. J Pain Symptom Manage. 2009;37(4):737-745.

16. Heymen S, Scarlett Y, Jones K, Ringel Y, Drossman D, Whitehead WE. Randomized, controlled trial shows biofeedback to be superior to alternative treatments for patients with pelvic floor dyssynergia-type constipation. Dis Colon Rectum. 2007;50(4):428-441.

17. Rao SS, Seaton K, Miller M, et al. Randomized controlled trial of biofeedback, sham feedback, and standard therapy for dyssynergic defecation. Clin Gastroenterol Hepatol. 2007;5(3):331-338.

18. Camilleri M, Lee JS, Viramontes B, Bharucha AE, Tangalos EG. Insights into the pathophysiology and mechanisms of constipation, irritable bowel syndrome, and diverticulosis in older people. JAm Geriatr Soc. 2000;48(9):1142-1150.

19. Simón MA, Bueno AM. Behavioural treatment of the dyssynergic defecation in chronically constipated elderly patients: a randomized controlled trial. Appl Psychophysiol Biofeedback. 2009;34(4):273-277.

20. Hanlon JT, Fillenbaum GG, Ruby CM, Gray S, Bohannon A. Epidemiology of over-the-counter drug use in community dwelling elderly: United States perspective. Drugs Aging. 2001;18(2):123-131.

21. Stoehr GP, Ganguli M, Seaberg EC, Echement DA, Belle S. Overthe-counter medication use in an older rural community: the MoVIES Project. J Am Geriatr Soc. 1997;45(2):158-165.

22. Goh LY, Vitry AI, Semple SJ, Esterman A, Luszcz MA. Self-medication with over-the-counter drugs and complementary medications in South Australia's elderly population. BMC Complement Altern Med. 2009;9:42.

23. Anraku M, Inoue H, Sato E, et al. Surveillance study in collaboration with a university-daycare center for elderly people and nursery school for children on the use of over-the-counter drugs and health food in Fukuyama. Yakugaku Zasshi. 2010;130(8):1093-1103. Japanese. 
24. Albert NM, Rathman L, Ross D, et al. Predictors of over-the-counter drug and herbal therapies use in elderly patients with heart failure. J Card Fail. 2009;15(7):600-606.

25. DiPalma JA, Cleveland MB, McGowan J, Herrera JL. A comparison of polyethylene glycol laxative and placebo for relief of constipation from constipating medications. South Med J. 2007;100(11):1085-1090.

26. DiPalma JA, Cleveland MV, McGowan J, Herrera JL. A randomized, multicenter, placebo-controlled trial of polyethylene glycol laxative for chronic treatment of chronic constipation. Am J Gastroenterol. 2007;102(7):1436-1441.

27. Lembo AJ, Kurtz CB, Macdougall JE, et al. Efficacy of linaclotide for patients with chronic constipation. Gastroenterology. 2010;138(3):886-895.

28. Mueller-Lissner S, Rykx A, Kerstens R, Vandeplassche L. Randomized double-blind placebo-controlled trial to evaluate efficacy and safety of prucalopride (Resolor ${ }^{\mathbb{R}}$ ) in elderly patients with chronic constipation. Gastroenterology. 2008;134(4 Suppl 1):A-157. Abstract 1052.

29. Camilleri M, Beyens G, Kerstens R, Robinson P, Vandeplassche L. Safety assessment of prucalopride in elderly patients with constipation: a double-blind, placebo-controlled study. Neurogastroenterol Motil. 2009;21(12):1256-e1117.

30. Fleming V, Wade WE. A review of laxative therapies for treatment of chronic constipation in older adults. Am J Geriatr Pharmacother. 2010;8(6):514-550.

31. Chamberlain SM, Rao SS. Safety evaluation of lubiprostone in the treatment of constipation and irritable bowel syndrome. Expert Opin Drug Saf. 2012;11(5):841-850.

32. Camilleri M, Bharucha AE, Ueno R, et al. Effect of a selective chloride channel activator, lubiprostone, on gastrointestinal transit, gastric sensory, and motor functions in healthy volunteers. Am J Physiol Gastrointest Liver Physiol. 2006;290(5):G942-G947.

33. Johanson JF, Ueno R. Lubiprostone, a locally acting chloride channel activator, in adult patients with chronic constipation: a double-blind, placebo-controlled, dose-ranging study to evaluate efficacy and safety. Aliment Pharmacol Ther. 2007;25(11):1351-1361.

34. Barish CF, Drossman D, Johanson JF, Ueno R. Efficacy and safety of lubiprostone in patients with chronic constipation. Dig Dis Sci. 2010; 55(4):1090-1097.

35. Suares NC, Ford AC. Efficacy of lubiprostone in the treatment of chronic idiopathic constipation: systematic review and meta-analysis. Gut. 2011;60 Suppl 1:A164-A165. Abstract.

36. Lembo AJ, Johanson JF, Parkman HP, Rao SS, Miner PB Jr., Ueno R. Long-term safety and effectiveness of lubiprostone, a chloride channel (ClC-2) activator, in patients with chronic idiopathic constipation. Dig Dis Sci. 2011;56(9):2639-2645.

37. Drossman DA, Chey WD, Johanson JF, et al. Clinical trial: lubiprostone in patients with constipation-associated irritable bowel syndrome - results of two randomized, placebo-controlled studies. Aliment Pharmacol Ther. 2009;29(3):329-341.

38. Chey WD, Drossman DA, Johanson JF, Scott C, Panas RM, Ueno R. Safety and patient outcomes with lubiprostone for up to 52 weeks in patients with irritable bowel syndrome with constipation. Aliment Pharmacol Ther. 2012;35(5):587-599.

39. Ueno R, Joswick TR, Wahle A, Zhu Y, Holland PC. Efficacy and safety of lubiprostone for the treatment of chronic constipation in elderly vs non-elderly subjects. Gastroenterology. 2006;130(Suppl 2):A189. Abstract S1262.

40. Ueno R, Panas R, Wahle A, Zhu Y, Holland PC. Long-term safety and efficacy of lubiprostone for the treatment of chronic constipation in elderly subjects. Gastroenterology. 2006;130 (Suppl 2):A-188. Abstract S1260.

41. Ueno R, Wahle A, Rivera E. Pooled analysis of the most frequent adverse events associated with the use of lubiprostone. Am J Gastroenterol. 2006;101(Supp1 2):S489. Abstract 1264.

42. Sprenger C, Copa A, Morganroth J, et al. Effect of lubiprostone, a unique agent for the treatment of chronic idiopathic constipation, on clinical electrocardiogram results. Gastroenterology. 2007;132:A325. Abstract.
43. Mostile G, Jankovic J. Treatment of dysautonomia associated with Parkinson's disease. Parkinsonism Relat Disord. 2009;15 Suppl 3: S224-S232.

44. Ondo WG, Kenney C, Sullivan K, et al. Placebo-controlled trial of lubiprostone for constipation associated with Parkinson disease. Neurology. 2012;78(21):1650-1654.

45. Krogh K, Christensen P. Neurogenic colorectal and pelvic floor dysfunction. Best Pract Res Clin Gastroenterol. 2009;23(4):531-543.

46. Honig H, Antonini A, Martinez-Martin P, et al. Intrajejunal levodopa infusion in Parkinson's disease: a pilot multicenter study of effects on nonmotor symptoms and quality of life. Mov Disord. 2009;24(10): 1468-1474.

47. Astarloa R, Mena MA, Sánchez V, de la Vega L, de Yébenes JG. Clinical and pharmacokinetic effects of a diet rich in insoluble fiber on Parkinson disease. Clin Neuropharmacol. 1992;15(5):375-380.

48. Ashraf W, Pfeiffer RF, Park F, Lof J, Quigley EM. Constipation in Parkinson's disease: objective assessment and response to psyllium. Mov Disord. 1997;12(6):946-951.

49. Sakakibara R, Yamaguchi T, Uchiyama T, et al. Calcium polycarbophil improves constipation in primary autonomic failure and multiple system atrophy subjects. Mov Disord. 2007;22(11):1672-1673.

50. Bassotti G, Maggio D, Battaglia E, et al. Manometric investigation of anorectal function in early and late stage Parkinson's disease. J Neurol Neurosurg Psychiatry. 2000;68(6):768-770.

51. Zangaglia R, Martignoni E, Glorioso M, et al. Macrogol for the treatment of constipation in Parkinson's disease. A randomized placebo-controlled study. Mov Disord. 2007;22(9):1239-1244.

52. Sadjadpour K. Pyridostigmine bromide and constipation in Parkinson's disease. JAMA. 1983;249(9):1148.

53. Jost WH, Schimrigk K. Long-term results with cisapride in Parkinson's disease. Mov Disord. 1997;12(3):423-425.

54. Cadeddu F, Bentivoglio AR, Brandara F, Marniga G, Brisinda G, Maria G. Outlet type constipation in Parkinson's disease: results of botulinum toxin treatment. Aliment Pharmacol Ther. 2005;22(10):997-1003.

55. Trescot AM, Glaser SE, Hansen H, Benyamin R, Patel S, Manchikanti L. Effectiveness of opioids in the treatment of chronic non-cancer pain. Pain Physician. 2008;11(Suppl 2):S181-S200.

56. Gianni W, Ceci M, Bustacchini S, et al. Opioids for the treatment of chronic non-cancer pain in older people. Drugs Aging. 2009;26 Suppl 1: S63-S73.

57. van Ojik AL, Jansen PA, Brouwers JR, van Roon EN. Treatment of chronic pain in older people: evidence-based choice of strong-acting opioids. Drugs Aging. 2012;29(8):615-625.

58. De Schepper HU, Cremonini F, Park MI, Camilleri M. Opioids and the gut: pharmacology and current clinical experience. Neurogastroenterol Motil. 2004;16(4):383-394.

59. Kalso E, Edwards JE, Moore RA, McQuay HJ. Opioids in chronic noncancer pain: systematic review of efficacy and safety. Pain. 2004;112(3): $372-380$.

60. Pappagallo M. Incidence, prevalence, and management of opioid bowel dysfunction. Am J Surg. 2001;182(Suppl 5A):S11-S18.

61. Webster L, Jansen JP, Peppin J, et al. Alvimopan, a peripherally acting mu-opioid receptor (PAM-OR) antagonist for the treatment of opioidinduced bowel dysfunction: results from a randomized, double-blind, placebo-controlled, dose-finding study in subjects taking opioids for chronic non-cancer pain. Pain. 2008;137(2):428-440.

62. Michna E, Blonsky ER, Schulman S, et al. Subcutaneous methylnaltrexone for treatment of opioid-induced constipation in patients with chronic, nonmalignant pain: a randomized controlled study. J Pain. 2011;12(5):554-562.

63. Itawi EA, Savoie LM, Hanna AJ, Apostolides GY. Alvimopan addition to a standard perioperative recovery pathway. JSLS. 2011;15(4): 492-498.

64. Sawh SB, Selvaraj IP, Danga A, Cotton AL, Moss J, Patel PB. Use of methylnaltrexone for the treatment of opioid-induced constipation in critical care patients. Mayo Clin Proc. 2012;87(3):255-259.

65. Gatti A, Sabato AF. Management of opioid-induced constipation in cancer patients: focus on methylnaltrexone. Clin Drug Investig. 2012; 32(5):293-301. 
66. Fei G, Raehal K, Liu S, et al. Lubiprostone reverses the inhibitory action of morphine on intestinal secretion in guinea pig and mouse. J Pharmacol Exp Ther. 2010;334(1):333-340.

67. Sun X, Wang X, Wang GD, et al. Lubiprostone reverses the inhibitory action of morphine on mucosal secretion in human small intestine. Dig Dis Sci. 2011;56(2):330-338.

68. Cryer BL, Katz S, Vallejo R, et al. A phase 3, randomised, double-blind, placebo controlled clinical trial of lubiprostone for the treatment of opioid-induced bowel dysfunction in patients with chronic non-cancer pain. Gastroenterology. 2010;138 Suppl 1:S-129. Abstract 906.

69. Jamal M, Mareya S, Woldegeorgis F, Joswick T, Ueno R. Lubiprostone significantly improves treatment response in non-methadone opioid-induced bowel dysfunction patients with chronic, noncancer pain: Results from a phase 3, randomized, double-blind, placebo-controlled clinical trial. Gastroenterology. 2012;142(5 Suppl 1): S144-S145. Abstract 848a.
70. Sucampo Pharmaceuticals. Takeda and Sucampo report top-line results of two phase 3 trials of lubiprostone in opioid-induced bowel dysfunction [press release]. Bethesda, MD: Sucampo Pharmaceuticals Inc; 2009 [Jul 21]. Available from: http://investor.sucampo.com/phoenix. zhtml?c=201197\&p=irol-newsArticle\&ID=1309679\&highlight=. 2009 . Accessed December 18, 2012.

71. Sucampo Pharmaceuticals. Positive top-line results from phase 3 long-term, open-label safety and efficacy trial of lubiprostone in opioid-induced bowel dysfunction patients [press release]. Bethesda, MD: Sucampo Pharmaceuticals; 2012 [Apr 5]. Available from: http://investor.sucampo.com/phoenix.zhtml?c=201197\&p=irolnews Article $\& I D=1680449 \&$ highlight $=$. 2012. Accessed December 18, 2012.
Clinical Interventions in Aging

\section{Publish your work in this journal}

Clinical Interventions in Aging is an international, peer-reviewed journal focusing on evidence-based reports on the value or lack thereof of treatments intended to prevent or delay the onset of maladaptive correlates of aging in human beings. This journal is indexed on PubMed Central, MedLine, the American Chemical Society's 'Chemical Abstracts Ser-

\section{Dovepress}

vice' (CAS), Scopus and the Elsevier Bibliographic databases. The manuscript management system is completely online and includes a very quick and fair peer-review system, which is all easy to use. Visit $\mathrm{http}: / /$ www.dovepress.com/testimonials.php to read real quotes from published authors.

Submit your manuscript here: http://www.dovepress.com/clinical-interventions-in-aging-journal 